\title{
Staining Maize Epidermal Leaf Peels with Toluidine Blue O
}

Marschal A. Bellinger, Sukhmani K. Sidhu and Carolyn G. Rasmussen*

Department of Botany and Plant Sciences, Center for Plant Cell Biology, Institute for Integrative Genome Biology, University of California, Riverside, U.S.A.

*For correspondence: carolyn.rasmussen@ucr.edu

[Abstract] Maize is an important model organism for understanding cell patterning and development. The regular patterning of maize leaf epidermal cells has previously been characterized using the dye toluidine blue $\mathrm{O}$ (TBO). The polychromatic dye TBO differentially stains plant cells depending on the chemical composition of cell components and has been used to identify differences in development, cell shape and wall composition in maize. This protocol provides step-by-step instructions to fix maize leaf tissue, to peel the maize epidermis, to stain epidermal peels with TBO and finally to image using a standard light microscope. The benefit of using epidermal peels is to generate high-quality micrographs of epidermal cells for quantitative analysis. TBO staining highlights cell walls, nuclei, and differential staining of different cell types that are simple to compare, and measure.

Keywords: Zea mays, Maize, Cell Division, Cell Wall, Toluidine Blue O, Cell Shape, Nucleus

[Background] Histological methods provide a reliable way to study plant cell morphology and anatomy with a focus on visualizing differences in cell wall composition. TBO, also known as Tolonium chloride $\left(\mathrm{C}_{15} \mathrm{H}_{16} \mathrm{~N}_{3} \mathrm{~S}^{+}\right)$, is a basic (cationic), dye that binds anionic groups in the cell and stains them distinct colors. Polyphenolic substances, such as lignin, are stained green-blue. Carboxylated polysaccharides, such as pectic acid, are stained pink-purple (Yeung, 1998). Nucleic acids are stained blue-purple. TBO has been used by plant biologists to understand the development, cellular anatomy and chemical makeup of cells for nearly one hundred years, but used more commonly after a landmark paper showed that it differentially stained different cell types and cell wall components (O'Brien et al., 1964). In Arabidopsis thaliana, TBO has been used on transverse sections of stems to identify xylem and phloem via differences in relative abundance of lignin in the secondary cell wall (Pradhan Mitra and Loqué, 2014; Verhertbruggen et al., 2017).

In Zea mays (maize), TBO has been used to understand the development, organization, shape and orientation of cell divisions (Smith et al., 1996; Gallagher and Smith, 1999; Cartwright et al., 2009; Wright et al., 2009; Frank et al., 2003; Rosa et al., 2017). TBO has been used to characterize defects in maize cell division and development such as found in discordia1 ( $d c d 1)$ and $d c d 2$ mutants with abnormal asymmetric subsidiary cell divisions (Gallagher and Smith, 1999) or symmetric and asymmetric division defects in tangled1 mutants (Smith et al., 1996; Martinez et al., 2017). Developmental defects in maize leaves have been studied using TBO on mutant plants (Moose and Sisco, 1994; Chuck et al., 2011) such as crinkly4 (cr4), a receptor-like kinase (Jin et al., 2000) and the adaxialized leaves of the semidominant Rolled leaf1-O mutant (Nelson et al., 2002; Juarez et al., 2004). TBO was used to analyze 
defective kernel1 (dek1) mutants in kernel cross-sections for analysis of the maize embryo (Becraft et al., 2002). Cell wall composition of maize leaf epidermis in corn rootworm beetles1 (crw1) mutant plants was revealed to be different from wild-type using TBO (Venkata et al., 2013). A recent study on the narrow odd dwarf 1 (nod1) mutant used TBO to show delays in the juvenile to adult leaf transition and defects in stomatal cell organization (Rosa et al., 2017).

Importantly, polychromatic TBO staining can be used to describe cell anatomy in plants lacking molecular tools. The popular use of TBO is exemplified by the numerous examples of fixation, dissection, and TBO staining in different plants (Regan and Moffatt, 1990; Ye and Varner, 1991; Cheng et al., 2000; Gao and Showalter, 2000; Tavakol et al., 2015; Murgia et al., 2017). Many of the examples referenced above use whole-mount leaf tissue and also epidermal peeling followed by TBO staining. If the focus is to observe multiple cell layers, cross-sections of whole-mount leaf tissue are used. When whole-mount leaves are used to examine epidermal cells, careful observation is required to analyze just epidermal cells while avoiding the cells below. If the focus is to gather high-quality quantitative information about epidermal cells, which play a critical role in development and growth, this method provides reliable and clean epidermal cell micrographs for analysis. Our protocol shows step-by-step epidermal leaf peeling and common troubleshooting during TBO staining for maize researchers.

\section{Materials and Reagents}

1. Frosted microscope glass slides

2. Coverslip

3. Weigh boat

4. Centrifuge tubes $(2 \mathrm{ml}, 15 \mathrm{ml}, 50 \mathrm{ml})$

5. Pipette tips $(200 \mu \mathrm{l}, 1,000 \mu \mathrm{l})$

6. Gloves

7. Wipes: Kimwipes, Delicate Task Wipers (Kimberly-Clark)

8. Scientific scale ruler

9. Paper towels

10. Adult leaves (leaf 8 or higher) from greenhouse grown 10-week-old Zea mays

11. Distilled water

12. Sodium Phosphate Monobasic $\left(\mathrm{NaH}_{2} \mathrm{PO}_{4}\right)$ (CAS: $\left.7558-80-7\right)$

13. Sodium Phosphate Dibasic $\left(\mathrm{NaHPO}_{4}\right)$ (CAS: 7558-79-4)

14. Ethylenediaminetetraacetic acid (EDTA, $\mathrm{C}_{10} \mathrm{H}_{16} \mathrm{~N}_{2} \mathrm{O}_{8}$ ) (CAS: 60-00-4)

15. Sodium Hydroxide ( $\mathrm{NaOH}$ ) (CAS: 1310-73-2)

16. Acetic Acid $\left(\mathrm{CH}_{3} \mathrm{COOH}\right)(\mathrm{CAS}: 64-19-7)$

17. Sodium Acetate $\left(\mathrm{C}_{2} \mathrm{H}_{3} \mathrm{NaO}_{2}\right)$ (CAS: 127-09-3)

18. Formaldehyde $\left(\mathrm{CH}_{2} \mathrm{O}\right)$ (CAS: 50-00-0)

19. Toluidine Blue $\mathrm{O}\left(\mathrm{C}_{15} \mathrm{H}_{16} \mathrm{~N}_{3} \mathrm{~S}^{+}\right)$(CAS: 92-31-9)

20. Pectolyase (Sigma-Aldrich, catalog number: P5936-100MG) 
21. Saponin (CAS: 8047-15-2)

22. $1 \mathrm{M}$ Sodium Phosphate Buffer $\left(\mathrm{Na}_{3} \mathrm{PO}_{4}\right)$ pH 7.2 Stock Solution (see Recipes)

23. $0.5 \mathrm{M}$ Ethylenediaminetetraacetic acid (EDTA, $\mathrm{C}_{10} \mathrm{H}_{16} \mathrm{~N}_{2} \mathrm{O}_{8}$ ) pH 8 Stock Solution (see Recipes)

24. 1 M Acetic Acid Stock Solution (see Recipes)

25. $0.1 \mathrm{M}$ Sodium Acetate (see Recipes)

26. 10x Fix Solution Stock Solution (see Recipes)

27. 1x Fix Solution (see Recipes)

28. Acetate Buffer $\mathrm{pH} 4$ (see Recipes)

29. $0.05 \%$ TBO Staining Solution $\mathrm{pH} 4$ (see Recipes)

30. $0.1 \%$ Pectolyase Solution (see Recipes)

\section{Equipment}

1. Scalpel

2. Fine forceps

3. Pipettes

4. Incubator

5. Light microscope

6. Rotisserie tube rotator

7. Fume hood

\section{Procedure}

A. Sampling maize leaf tissue

1. Remove the leaf blade at a measured distance from the ligule as shown in Figure $1 \mathrm{~A}$.

2. Cut out $1 \mathrm{~cm} \times 1 \mathrm{~cm}$ sections from leaf blade sample approximately $10 \mathrm{~cm}$ from the ligule as shown in Figure 1B. Multiple sections can be taken from one leaf blade but it is critical to use leaf samples from the same measured distance from the ligule if comparing different leaf samples with each other.

3. Immediately place sections into a $2 \mathrm{ml}$ tube containing $1 \mathrm{ml}$ of $1 \mathrm{x}$ fix solution. The same tube can be used for all of the following steps. It is important to keep the sample in liquid as it is processed for imaging.

4. Incubate sections at room temperature $\left(\sim 21^{\circ} \mathrm{C}\right)$ in a tube rotator in $1 \mathrm{x}$ fix solution for $>2 \mathrm{~h}$. Leaf sections can then be stored for months in $1 \mathrm{x}$ fix solution at $4{ }^{\circ} \mathrm{C}$.

5. Remove $1 x$ fix solution from the $2 \mathrm{ml}$ tube containing the sections.

6. Add $1 \mathrm{ml}$ distilled water and invert the tube for $1 \mathrm{~min}$ to wash sections.

7. Remove excess water by decanting and repeat wash step 3-5 times.

8. Remove all distilled water from the $2 \mathrm{ml}$ tube containing the washed sections. 
9. Add $1 \mathrm{ml}$ of freshly prepared $0.1 \%$ pectolyase solution to the $2 \mathrm{ml}$ tube containing the washed sections. Pectolyase solution should be prepared from free-flowing fresh pectolyase and used immediately.

10. Incubate sections at room temperature $\left(-21^{\circ} \mathrm{C}\right)$ in a tube rotator for $1-3 \mathrm{~h}$.

11. Remove $0.1 \%$ pectolyase solution from the $2 \mathrm{ml}$ tube containing the sections.

12. Add $1 \mathrm{ml}$ distilled water and invert the tube for $1 \mathrm{~min}$ to wash sections.

13. Remove excess water by decanting and repeat wash step 3-5 times.

14. Add $1 \mathrm{ml}$ of distilled water to an empty tube containing the washed sections. These sections can be stored for at least two weeks at $4{ }^{\circ} \mathrm{C}$ in $1 \mathrm{ml}$ of distilled water.

B. Peeling the epidermal cell layer away from the leaf tissue section

1. Add $200 \mu$ listilled water to a weigh boat.

2. Place a leaf section into the distilled water as shown in Figure $1 \mathrm{C}$.

3. Starting from a corner of the leaf tissue section, use a dull scalpel and fine forceps to gently lift up either adaxial or abaxial epidermal cell layers as shown in Figure 1D and Video 1. We typically use the abaxial epidermal cell layer due to its simple patterning and lack of brightly purple or dark blue staining bulliform cells.

4. Once a small strip of the epidermis has been lifted away, use a pair of fine forceps to take hold of this tissue layer. Even a small strip of leaf epidermis contains hundreds of cells.

5. Holding the leaf tissue section with one pair of forceps and the epidermis with another pair of forceps, pull both tissues away from each other slowly.

6. Place the peel into a $100 \mu \mathrm{l}$ drop of TBO staining solution in a weigh boat.

7. Incubate at room temperature for 10-15 min.

8. Take the peel out of the drop of TBO and place it into a fresh $100 \mu \mathrm{l}$ drop of distilled water for 530 min to destain as shown in Figure $1 \mathrm{E}$ and Video 1.

9. Mount the peel in a $50 \mu \mathrm{l}$ drop of distilled water on a frosted glass slide and cover with a coverslip as shown in Figure 1F.

10. Make sure sample lays flat and all air bubbles have been evacuated from the sample.

11. Use a Kimwipe to remove excess water. The coverslip can be sealed with nail-polish for longer examination of TBO stained material, but strong staining doesn't last for more than a day or two.

12. The sample is now ready to be observed with a light microscope and pictures taken as shown in Figures $1 \mathrm{G}$ and $1 \mathrm{H}$. 

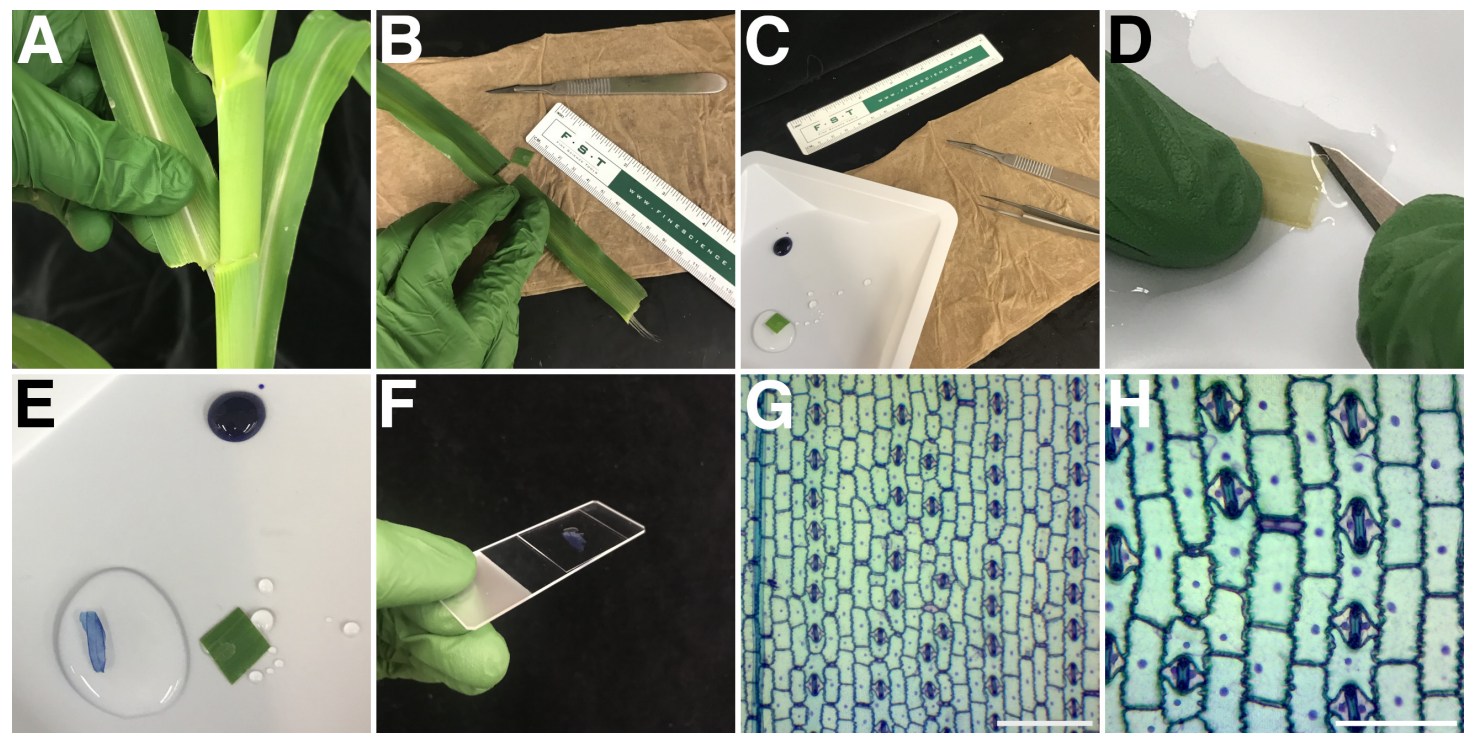

Figure 1. Leaf dissection and section processing. Maize leaf dissection, epidermal peeling, TBO staining, and representative light microscope images of adult maize adaxial leaf blades. A. Removal of the leaf blade at the ligule. B. A $1 \mathrm{~cm} \times 1 \mathrm{~cm}$ square of leaf tissue removed from approximately $10 \mathrm{~cm}$ away from the ligule. C. Following pectolyase digestion, the solutions (distilled water and TBO) and tools (weigh boat, forceps, scalpel, and ruler) used in the dissection and staining of the leaf section. D. Removal of the epidermal cell layer using a dull scalpel and forceps. Leaf section will remain bright green if processed immediately but turns pale yellow over time. E. Epidermal section peel after it has been removed and stained with TBO as it destains in water (left). F. A slide mounted with an epidermal section peel. G. Light microscope image of an epidermal section peel taken at 40x magnification, scale bar is $200 \mu \mathrm{m}$. F. Light microscope image of an epidermal section peel taken at 100x magnification. Scale bar is $100 \mu \mathrm{m}$.

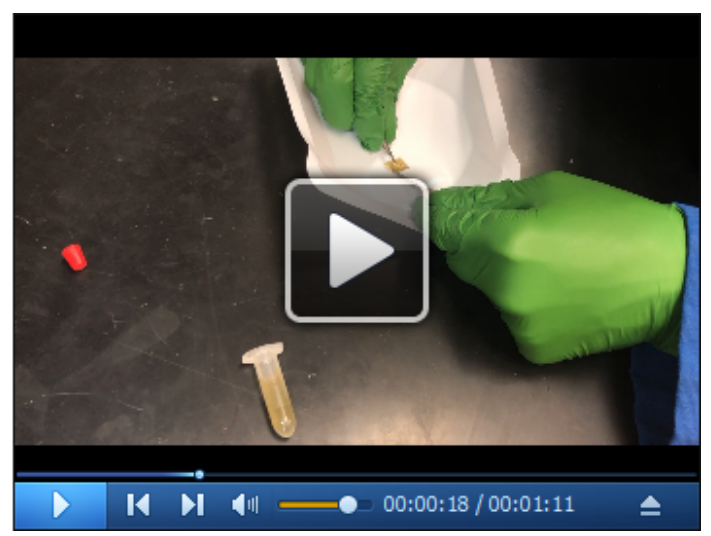

Video 1. Movie showing how to peel and stain maize leaf epidermis following the pectolyase digestion step 


\section{Data analysis}

TBO is a cationic, dye that changes color as it interacts with different cellular components. Nucleic acids appear blue-purple, polyphenolic substances appear green-blue and carboxylated polysaccharides appear pink-purple after TBO staining (Yeung, 1998). Maize nuclei appear bluepurple (Figure 2A), mature epidermal cells appear light blue (Figure $2 A$ ), cell walls appear greenblue (Figure 2A), subsidiary cells appear pink-violet (Figure 2A), cork cells appear pink-violet (Figure $2 A$ ), bulliform cells appear pink-violet (Figure 2B), and leaf blade macrohair cells appear green-blue (Figure 2B). Please note that juvenile maize leaves have more uniform pink-purple staining of all epidermal cells (Sylvester and Smith, 2009; Rosa et al., 2017). Maize juvenile leaf cells stain pinkpurple uniformly because juvenile cell walls are less lignified.

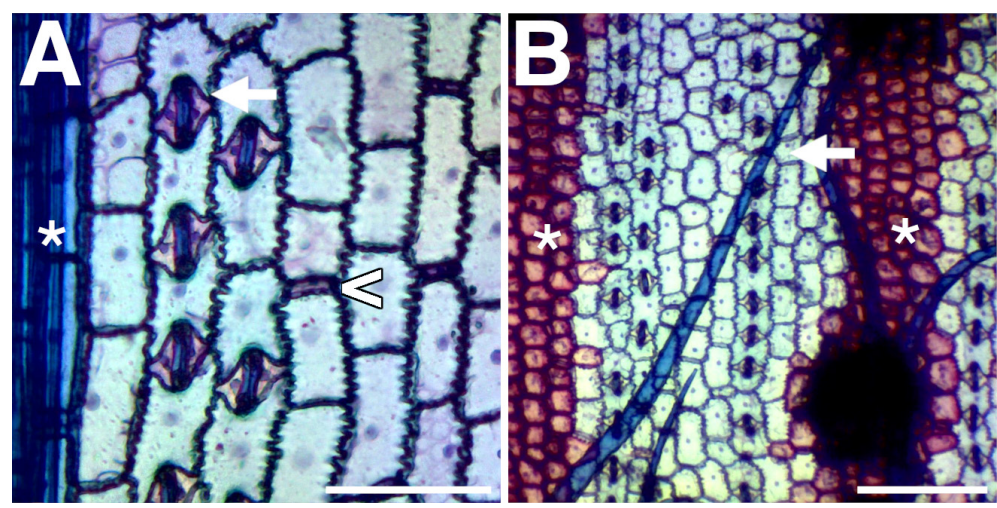

Figure 2. The effect of TBO staining on different cell types and nuclei of the maize leaf epidermis. A. An image of cells from an abaxial epidermis peel taken at 100x magnification. The asterisk shows highly lignified blue-green vascular bundle cells. The white arrow points to a pair of pink subsidiary cells surrounding the guard cells that form the stomatal complex. The white caret points to a violet-pink cork cell. Scale bar is $100 \mu \mathrm{m}$. B. An image of cells from an adaxial epidermis peel taken at 40x magnification, scale bar is $200 \mu \mathrm{m}$. The white arrow points to a blue macrohair cell. The white asterisks show dark pink-purple bulliform cell files. Epidermal section peels were imaged by light microscope.

\section{Notes}

1. Always work in a fume hood and wear personal protective equipment recommended by your institution when handling dangerous chemicals such as formaldehyde and glacial acetic acid. Dispose of chemicals according to your institution's policies.

2. Exercise caution and follow your institution's safety and disposal procedures while handling sharps, including blades and glass.

3. Use freshly prepared $1 x$ fix solution, as formaldehyde can precipitate in solution, decreasing its effective concentration over time. 
4. Samples can be stored indefinitely at $4{ }^{\circ} \mathrm{C}$ in fixative solution for future use. Images of Figures $1 \mathrm{D}, 1 \mathrm{G}$ and $1 \mathrm{H}$ were taken from samples that were in fixation solution for over a year.

5. Use fresh, free flowing pectolyase. If the pectolyase is clumpy, then it should not be used anymore. Pectolyase is a hygroscopic powder that reacts with water in the air and quickly becomes less effective at digesting plant cell walls after exposure to water.

6. Leaf sections will easily fall apart if left to digest in pectolyase solution for too long. Start with a new sample from the fixative solution and reduce digestion in pectolyase solution by $30 \mathrm{~min}$.

7. To check if the sample is ready to peel, try removing the top layer of abaxial epidermal cells as shown in Video 1.

8. The adaxial epidermis is more difficult to peel and tears more easily. Do not be discouraged, as even small peels contain many cells.

9. If the epidermis does not readily peel away from the leaf (green tissue comes up with the epidermis) the pectolyase digestion is incomplete (Figure $3 \mathrm{~A}$ ). Allow the sample to incubate longer in $0.1 \%$ pectolyase solution ( $-30 \mathrm{~min}$ increments).

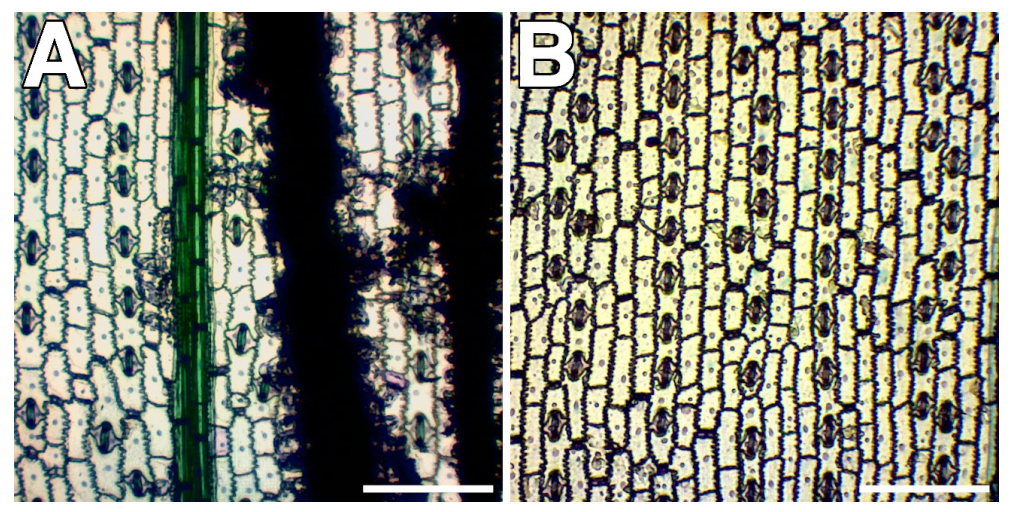

Figure 3. Examples of common problems that occur during peeling or staining. A. An abaxial epidermal tissue peel that has not been fully digested in $0.1 \%$ pectolyase solution still has a lot of green material from mesophyll and other cell layers after peeling. B. An abaxial epidermal tissue peel that not been adequately incubated in TBO doesn't brightly stain the subsidiary cells. Light microscope images of epidermal section peels were taken at 40x magnification, scale bar is $200 \mu \mathrm{m}$.

10. Maintaining the low $\mathrm{pH}$ of the solutions is important because TBO is only polychromatic at $\mathrm{pH}$ 4.4 or lower. Higher pH samples turn blue only.

11. Slides can be sealed with clear nail polish to hold for a day or two.

12. Peeled maize leaf epidermis will crack or lose TBO staining if allowed to dry out. Always keep samples in solutions or distilled water.

13. If the cells appear too lightly stained (Figure 3B), the staining step can be repeated. Alternatively, consider destaining for a smaller time increment. 


\section{Recipes}

1. $1 \mathrm{M}$ Sodium Phosphate Buffer $\left(\mathrm{Na}_{3} \mathrm{PO}_{4}\right) \mathrm{pH} 7.2$ Stock Solution

To make $1 \mathrm{~L}$ of $1 \mathrm{M} \mathrm{Na}_{3} \mathrm{PO}_{4}$ Buffer $\mathrm{pH}$ 7.2:

Add $\sim 280 \mathrm{ml} 1 \mathrm{M}$ Sodium Phosphate Monobasic $\left(\mathrm{NaH}_{2} \mathrm{PO}_{4}\right)$

Add $\sim 720 \mathrm{ml} 1 \mathrm{M}$ Sodium Phosphate Dibasic $\left(\mathrm{NaHPO}_{4}\right)$

If the $\mathrm{pH}$ of solution is too high, add additional $1 \mathrm{M} \mathrm{NaH}_{2} \mathrm{PO}_{4}$ to $\mathrm{pH} 7.2$

If the $\mathrm{pH}$ of solution is too low, add additional $1 \mathrm{M} \mathrm{NaHPO}_{4}$ to $\mathrm{pH} 7.2$

2. $0.5 \mathrm{M}$ Ethylenediaminetetraacetic acid (EDTA, $\left.\mathrm{C}_{10} \mathrm{H}_{16} \mathrm{~N}_{2} \mathrm{O}_{8}\right) \mathrm{pH} 8$ Stock Solution

Add Sodium Hydroxide $(\mathrm{NaOH})$ pellets until the EDTA starts to dissolve, then add $10 \mathrm{M} \mathrm{NaOH}$ until pH 8 is reached

3. $1 \mathrm{M}$ Acetic Acid Stock Solution

To make $1 \mathrm{~L}$ of $1 \mathrm{M}$ Acetic Acid $\left(\mathrm{CH}_{3} \mathrm{COOH}\right)$ :

Add $57.5 \mathrm{ml}$ of Glacial Acetic Acid (17.4 M)

Add $942.5 \mathrm{ml}$ of distilled water

4. $0.1 \mathrm{M}$ Sodium Acetate

To make $1 \mathrm{~L}$ of $0.1 \mathrm{M}$ Sodium Acetate $\left(\mathrm{C}_{2} \mathrm{H}_{3} \mathrm{NaO}_{2}\right)$ :

Add $8.2 \mathrm{~g}$ sodium acetate and fill to $1 \mathrm{~L}$ with distilled water

5. 10x Fix Solution Stock Solution

$0.5 \mathrm{M} \mathrm{Na}_{3} \mathrm{PO}_{4}$

$0.05 \mathrm{M}$ EDTA

2\% Saponin

6. 1x Fix Solution

Add $1 \mathrm{ml}$ of $10 x$ Fix stock solution

Add $1 \mathrm{ml}$ of formaldehyde ( $40 \%$ by volume)

Add $8 \mathrm{ml}$ of distilled water

7. Acetate Buffer $\mathrm{pH} 4$

Add $84.7 \mathrm{ml} 1 \mathrm{M}$ Acetic acid

Add $153 \mathrm{ml} 0.1 \mathrm{M}$ Sodium Acetate

Add $762.3 \mathrm{ml}$ of distilled water

8. $0.05 \%$ TBO Staining Solution $\mathrm{pH} 4$

Add $0.02 \mathrm{~g}$ of Toluidine Blue $\mathrm{O}$

Add $40 \mathrm{ml}$ of Acetate Buffer $\mathrm{pH} 4$

9. $\quad 0.1 \%$ Pectolyase Solution

Add $0.01 \mathrm{~g}$ of Pectolyase

Add $10 \mathrm{ml}$ of distilled water 


\section{Acknowledgments}

NSF-MCB \#1716972 is acknowledged for funding. Rasmussen lab members and Professor Michelle Facette (University of Massachusetts, Amherst) are acknowledged for their helpful review of this protocol. Professor Amanda J. Wright (University of North Texas) is gratefully acknowledged for sharing technical tips on this protocol, which is modified from (Gallagher and Smith, 1999; Wright et al., 2009).

\section{Competing interests}

All authors declare no competing interests.

\section{References}

1. Becraft, P. W., Li, K., Dey, N. and Asuncion-Crabb, Y. (2002). The maize dek1 gene functions in embryonic pattern formation and cell fate specification. Development 129(22): 5217-5225.

2. Cartwright, H. N., Humphries, J. A. and Smith, L. G. (2009). PAN1: a receptor-like protein that promotes polarization of an asymmetric cell division in maize. Science 323(5914): 649-651.

3. Cheng, J. C., Lertpiriyapong, K., Wang, S. and Sung, Z. R. (2000). The role of the Arabidopsis ELD1 gene in cell development and photomorphogenesis in darkness. Plant Physiol 123(2): 509-520.

4. Chuck, G. S., Tobias, C., Sun, L., Kraemer, F., Li, C., Dibble, D., Arora, R., Bragg, J. N., Vogel, J. P., Singh, S., Simmons, B. A., Pauly, M. and Hake, S. (2011). Overexpression of the maize Corngrass1 microRNA prevents flowering, improves digestibility, and increases starch content of switchgrass. Proc Natl Acad Sci U S A 108(42): 17550-17555.

5. Frank, M. J., Cartwright, H. N. and Smith, L. G. (2003). Three Brick genes have distinct functions in a common pathway promoting polarized cell division and cell morphogenesis in the maize leaf epidermis. Development 130(4): 753-762.

6. Gallagher, K. and Smith, L. G. (1999). Discordia mutations specifically misorient asymmetric cell divisions during development of the maize leaf epidermis. Development 126(20): 4623-4633.

7. Gao, M. and Showalter, A. M. (2000). Immunolocalization of LeAGP-1, a modular arabinogalactan-protein, reveals its developmentally regulated expression in tomato. Planta 210(6): 865-874.

8. Jin, P., Guo, T. and Becraft, P. W. (2000). The maize CR4 receptor-like kinase mediates a growth factor-like differentiation response. Genesis 27(3): 104-116.

9. Juarez, M. T., Kui, J. S., Thomas, J., Heller, B. A. and Timmermans, M. C. (2004). microRNAmediated repression of rolled leaf1 specifies maize leaf polarity. Nature 428(6978): 84-88. 
10. Martinez, P., Luo, A., Sylvester, A. and Rasmussen, C. G. (2017). Proper division plane orientation and mitotic progression together allow normal growth of maize. Proc Natl Acad Sci U S A 114(10): 2759-2764.

11. Moose, S. P. and Sisco, P. H. (1994). Glossy15 controls the epidermal juvenile-to-adult phase transition in maize. Plant Cell 6(10): 1343-1355.

12. Murgia, M. L., Attene, G., Rodriguez, M., Bitocchi, E., Bellucci, E., Fois, D., Nanni, L., Gioia, T., Albani, D. M., Papa, R. and Rau, D. (2017). A comprehensive phenotypic investigation of the "Pod-Shattering Syndrome" in common bean. Front Plant Sci 8: 251.

13. Nelson, J. M., Lane, B. and Freeling, M. (2002). Expression of a mutant maize gene in the ventral leaf epidermis is sufficient to signal a switch of the leaf's dorsoventral axis. Development 129(19): 4581-4589.

14. O'Brien, T. P., Feder, N. and McCully, M. E. (1964). Polychromatic staining of plant cell walls by toluidine blue O. Protoplasma 59: 368-373.

15. Pradhan Mitra, P. and Loque, D. (2014). Histochemical staining of Arabidopsis thaliana secondary cell wall elements. J Vis Exp (87).

16. Regan, S. M. and Moffatt, B. A. (1990). Cytochemical analysis of pollen development in wildtype Arabidopsis and a male-sterile mutant. Plant Cell 2(9): 877-889.

17. Rosa, M., Abraham-Juarez, M. J., Lewis, M. W., Fonseca, J. P., Tian, W., Ramirez, V., Luan, S., Pauly, M. and Hake, S. (2017). The maize MID-COMPLEMENTING ACTIVITY Homolog CELL NUMBER REGULATOR13/NARROW ODD DWARF coordinates organ growth and tissue patterning. Plant Cell 29(3): 474-490.

18. Smith, L. G., Hake, S. and Sylvester, A. W. (1996). The tangled-1 mutation alters cell division orientations throughout maize leaf development without altering leaf shape. Development 122(2): 481-489.

19. Sylvester, A. W. and Smith, L. G. (2009). Cell biology of maize leaf development. In: Handbook of Maize: Its Biology. Bennetzen, J. L. and Hake, S. C. (Eds.). Springer, New York. pp. 179-203.

20. Tavakol, E., Okagaki, R., Verderio, G., Shariati, J. V., Hussien, A., Bilgic, H., Scanlon, M. J., Todt, N. R., Close, T. J., Druka, A., Waugh, R., Steuernagel, B., Ariyadasa, R., Himmelbach, A., Stein, N., Muehlbauer, G. J. and Rossini, L. (2015). The barley Uniculme4 gene encodes a BLADE-ON-PETIOLE-like protein that controls tillering and leaf patterning. Plant Physiol 168(1): 164-174.

21. Venkata, B. P., Lauter, N., Li, X., Chapple, C., Krupke, C., Johal, G. and Moose, S. (2013). crw1-A novel maize mutant highly susceptible to foliar damage by the western corn rootworm beetle. PLoS One 8: e71296.

22. Verhertbruggen, Y., Walker, J. L., Guillon, F. and Scheller, H. V. (2017). A comparative study of sample preparation for staining and immunodetection of plant cell walls by light microscopy. Front Plant Sci 8: 1505. 
23. Wright, A. J., Gallagher, K. and Smith, L. G. (2009). discordia1 and alternative discordia1 function redundantly at the cortical division site to promote preprophase band formation and orient division planes in maize. Plant Cell 21(1): 234-247.

24. Yeung, E. C. (1998). A Beginner's guide to the study of plant structure. Proceedings of the 19th Workshop/Conference of the Association for Biology Laboratory Education 19: Pages 125-142.

25. Ye, Z. H. and Varner, J. E. (1991). Tissue-specific expression of cell wall proteins in developing soybean tissues. Plant Cell 3(1): 23-37. 